\title{
Dynamics of concentrations of total organic carbon in Estonian streams, 1992-2007
}

\author{
J. Pärn, L. Randmaa \& Ü. Mander \\ Department of Geography, Institute of Ecology and Earth Sciences, \\ University of Tartu, Estonia
}

\begin{abstract}
Human activities have begun to transform northern peatlands into global sources of dissolved organic carbon (DOC). In Estonia, there are $10,091 \mathrm{~km}^{2}$ of peatlands, constituting $22.3 \%$ of the country's total area. The increasing number of drought days during the last 50 years, which constitutes a threat of an increased flux of dissolved carbon, has also been observed in Estonia. The aim of the current study was to explain organic carbon trends in Estonian streams during the period 1992-2007. The national environmental monitoring programme initiated the measurement of total organic carbon (TOC) in Estonian streams in 1998. We reconstructed the earlier concentrations of TOC through the link with permanganate oxygen consumed (POC). The TOC and POC data of 64 weirs was studied. The determination coefficients between TOC and POC were over 0.75 for the nine North Estonian streams (Kasari, Vihterpalu, Vääna, Keila, Pirita, Jägala, Pudisoo Valgejõgi and Loobu). The $\mathrm{R}^{2}$ values in the rest of the sampled weirs were below 0.7. Likewise, the temporal trend of both TOC and POC data was insignificant. In northern Estonia, a weak but significant $\left(\mathrm{R}^{2}=0.09, \mathrm{p}<0.05\right)$ rising trend in TOC concentrations was observed. This may have resulted from the high percentage of peatlands and more calcareous soils in northern Estonian catchments. The trend corresponds with earlier data from northern catchments, being influenced by the effects of global warming and/or changes in the chemistry of atmospheric deposition, and demonstrating a complex positive feedback in the global C cycle.
\end{abstract}

Keywords: bog, catchment, climate change, enzymic latch, landscape, mire, sulphate deposition $\square$ 


\section{Introduction}

Northern peatlands comprise a third of the global soil carbon pool [1]. This accounts for $60 \%$ of the atmospheric carbon pool [2]. Global warming has begun to destabilise the sinks, gradually turning them into sources of DOC (dissolved organic carbon), with potentially serious implications for global warming $[2,3]$. The annual carbon sequestration rate in Baltic mires is estimated at $8-55 \mathrm{t} \mathrm{C} \mathrm{km}^{-2}$ [4].

In Estonia, there are $10,091 \mathrm{~km}^{2}$ of peatlands, constituting $22.3 \%$ of the country's total area. These are situated under various moisture regimes and management practices, ranging from bogs and swamps to artificially drained forests and agricultural fields on peatlands [5]. Aerobic conditions caused by man-made drainage initiate a rapid mineralisation of peat into $\mathrm{CO}_{2}, \mathrm{CH}_{4}$ and DOC

\subsection{Dependence of DOC on climate}

DOC is transported by water discharge, which depends on precipitation. High positive correlations between DOC and precipitation and discharge have been observed in the Õhne and Väike Emajõgi rivers in Estonia [6] and the North Bothnian Torne, Kalix and Råne rivers [7].

In mires, the anaerobic conditions prevent the enzyme phenol oxidase from removing phenolic compounds that inhibit biological decomposition. Freeman et al [3] have suggested that oxygen limitation on a single mire enzyme may be all that prevents the release of the northern peatland carbon stock into the atmosphere (enzymic latch). Droughts specifically cause peat aeration [3].

The number of extremely dry or rainy days has increased in Estonia between 1957 and 2006. The yearly variation in droughts and wet spells has risen simultaneously $[8,9]$. In the neighbouring climatic conditions of Southern Sweden, a slight trend towards prolonged hydrological droughts was observed since the 1960s [10]. Between now and the 2070s in Estonia, models simulate a rising trend in drought risk and gradually drier soils in summer [11, 12].

Moreover, the percentage variation follows a medially decreasing pattern as the diameter D increases. Basically, the experimental tests show that, with all other conditions being equal, the truncated cone foundation has a more favourable shape coefficient.

\subsection{Dependence of DOC on geochemistry}

One major reason for an increase in DOC in North European catchments may be a decrease in $\mathrm{SO}_{4}^{2-}$ (sulphate ion), causing a greater dissolution of soil organic carbon. Specifically, the reduction of the $\mathrm{SO}_{4}{ }^{2-}$ deposition resulting from smaller atmospheric pollution prohibits the methane-producing archaea [13, 14]. This mechanism has been suggested to cause an increase in DOC export from the 
water bodies of Great Britain from the mid-1990s to the mid-2000s [15]. The atmospheric deposition of nitrogen compounds can also affect the soil chemistry in a manner that increases the export of DOC [16]. Furthermore, Roulet and Moore argue that the export of DOC is probably determined by multiple related geochemical factors [17]. In Estonia, the post-Soviet re-organisation of industry lead to a great decrease in the atmospheric deposition of $\mathrm{SO}_{4}{ }^{2-}$ and nitrogen compounds in the 1990s [18].

\subsection{Objective}

The aim of this work is to explain the dynamics of DOC in Estonian rivers in the period 1992-2007. Connections to water chemistry, meteorological seasons, and the land cover of the catchment are discussed.

\section{Material and methods}

As proxies of DOC, we used POC (permanganate oxygen consumption) and TOC (total organic carbon). The Estonian national environmental monitoring programme initiated the measurements of POC and TOC in Estonian streams in 1992. TOC measurements began in 1998. The monitoring programme was divided geographically between four projects: northern, northeastern, southern and southwestern Estonia (Figure 1).

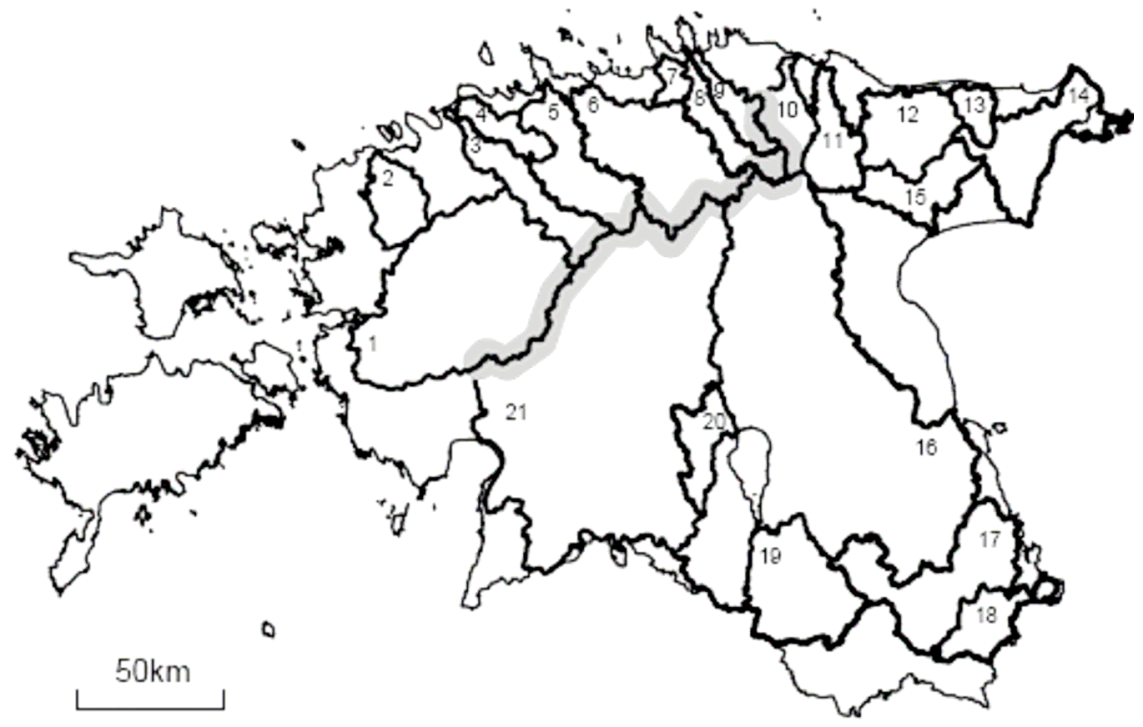

Figure 1: Studied catchments in northern (1-9), northeastern (10-15), southern (16-20) and southwestern Estonia (21). Grey line indicates the border between northern catchments and the rest of studied area. 
Water samples were subsequently collected and analysed by the Department of Environmental Engineering of the Tallinn University of Technology (northern Estonia), the affiliate laboratory of OÜ Eesti Keskkonnauuringute Keskus in Viru County (northeastern Estonia), OÜ Tartu Keskkonnauuringud (southern Estonia) and the affiliate laboratory of OÜ Eesti Keskkonnauuringute Keskus in Pärnu County (southwestern Estonia). Weirs were selected in order to determine the transport of pollutants through the main rivers in Estonia to the Baltic Sea, Lake Peipus and Lake Võrtsjärv. The number of weirs has varied between 58 and 65 during the period. Water was sampled from 6 to 12 times a year. The data can be freely downloaded in the directory of http://loodus.keskkonnainfo.ee.

We reconstructed the earlier concentrations of TOC through links with the permanganate oxygen consumed (POC) [19] and the biochemical oxygen demand (BOD). The time series were divided into four geographic subsets according to the national water monitoring projects. We ran a time series regression analysis on the data sets.

\section{Results}

The regression analysis showed that in no rivers did the $\mathrm{R}^{2}$ between the BOD and the TOC exceed the previously set threshold of 0.7 . The determination coefficients between TOC and POC were over 0.75 for the nine northern Estonian streams. Following numbers indicate location in Figure 1: the Kasari (1), Vihterpalu (2), Vääna (3), Keila (4), Pirita (5), Jägala (6), Loobu (7), Valgejõgi (8) and Pudisoo (9) streams. The $\mathrm{R}^{2}$ between POC and TOC in the rivers of northeastern, southern and southwestern Estonia was below 0.7: in the Selja (10), Kunda (11), Purtse (12), Pühajõgi (13), Narva (14), Rannapungerja (15), Suur Emajõgi (16), Võhandu (17), Piusa (18), Väike Emajõgi (19), Tänassilma (20), and Pärnu (21) streams. The time series of TOC were extended by the regression between PHT and TOC in northern Estonia $\left(\mathrm{y}=0.70 \mathrm{x}+3.28[\mathrm{mg} / \mathrm{L}] ; \mathrm{R}^{2}=0.87\right)$. The $\mathrm{R}^{2}$ in the rest of the sampled weirs was below 0.7 .

In northern Estonia, a weak but significant rising trend in TOC concentrations was observed $\left(\mathrm{R}^{2}=0.09, \mathrm{p}<0.05\right.$; Figure 2$)$. The trend equation was $\mathrm{y}=0,001 \mathrm{x}-23.53$, where $\mathrm{y}$ was the concentration of TOC and $\mathrm{x}$ was the time expressed in days of the C.E. system. In other geographic subsets, the temporal trend of both TOC and POC data was insignificant.

\section{Discussion}

There are probably multiple causes for the significant trend that appears only in northern Estonian streams. One possible distinction may result from technical differences between the laboratories carrying out the monitoring projects. The distinction may also be because of the higher percentage of peatlands, so the trend is more straightforward. A greater share of calcareous soils in northern Estonia may be another distinguishing factor as suggested by Cirmo and Driscoll [20], decreasing the influence of atmospheric deposition. 


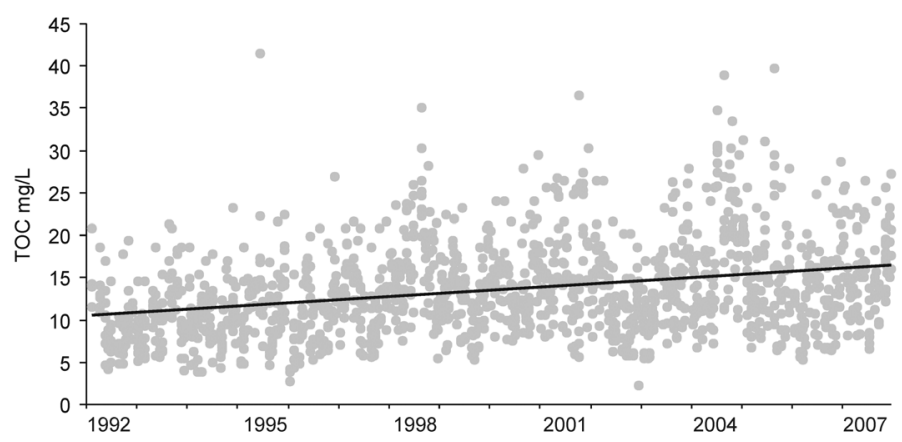

Figure 2: $\quad$ Trend of TOC concentration in northern Estonian streams $(\mathrm{y}=$ $\left.0,001 \mathrm{x}-23.53 ; \mathrm{R}^{2}=0.09 ; \mathrm{p}<0.05\right)$.

The observed positive trend in TOC corresponds with earlier data from northern catchments influenced by the global warming effects [3]. We did not conduct correlation analyses with meteorological, water chemical or soil parameters. However, the rising trend of TOC is in accordance with the suggested dependence on the amount of precipitation, discharge $[6,7]$ and the observed and modelled increase in the number of drought days [8-12]. The trend may also be caused by changes in atmospheric deposition chemistry $[15,18]$, and probably demonstrates a complex positive feedback in the global carbon cycle $[2,3,17]$.

\section{Conclusion}

We observed a small but significant trend towards an increase in total organic carbon concentrations in northern Estonian streams. We suggest that a complex interaction between increasing droughts and decreasing atmospheric sulphate deposition is the driving mechanism for this. No significant trend appeared in northeastern, southern and southeastern Estonian streams, which may be due to the more acidic soils and the lower share of peatlands. Technical differences between the monitoring projects may also cause the North Estonian streams to show a clearer trend.

\section{Acknowledgements}

This study was supported by the Estonian Science Foundation grant No. 7527 and Target Funding Project SF0180127s08 of the Estonian Ministry of Education and Research. We sincerely thank Ms. Ülle Leisk from the Department of Environmental Engineering of the Tallinn University of Technology for the data and comments and Ms. Kristina Sohar for the design of a chart. 


\section{References}

[1] Gorham, E., Northern peatlands, role in the carbon cycle and probable responses to climate warming. Ecological Applications 1, 182-195. 1991.

[2] Oechel W.C., Hastings S.J., Vourlitis G., Jenkins M.A., Riechers G. \& Grulke N., Recent change of arctic tundra ecosystems from a carbon sink to a source. Nature 361, 520-523. 1993.

[3] Freeman, C., Ostle, N. \& Kang, H., An enzymic 'latch' on a global carbon store. Nature 409, 149. 2001

[4] Jansson, Å., Folke, C., Rockström, J. \& Gordon, L., Linking freshwater flows and ecosystem services appropriated by people: The case of the Baltic Sea basin. Ecosystems 2, 351-366. 1999.

[5] Allikvee, H. \& Ilomets, M., Sood ja nende areng (Mires and their development). In: A. Raukas (ed.). Estonia: Nature, pp. 327-347. Valgus, Estonian Encyclopaedia Publishers, Tallinn, 1995. In Estonian.

[6] Nõges, P., Kägu, M. \& Nõges, T., Role of climate and agricultural practice in determining matter discharge into large, shallow Lake Võrtsjärv, Estonia. Hydrobiologia 581, 125-134. 2007.

[7] Smith, B., Aasa, A., Ahas, R., Blenckner, T., Callaghan, T.V., de Chazal, J., Humborg, C., Jönsson, A.M., Kellomäki, S., Kull, A., Lehikoinen, E., Mander, Ü., Nõges, P., Nõges, T., Rounsevell, M., Sofiev, M., Tryjanowski, P. \& Wolf, A., Climate-related Change in Terrestrial and Freshwater Ecosystems. In: The BACC Author Team. Assessment of Climate Change for the Baltic Sea Basin, pp. 221-284. Springer, Berlin, Heidelberg, 2008.

[8] Tammets, T., Changes in frequency of extreme wet and dry conditions in Estonia. In: Proceedings of International Conference on Climate Change: Impacts and Responses in Central and Eastern European Countries, pp. 87-93. Pecs, 2005.

[9] Tammets, T., Distribution of extreme wet and dry days in Estonia in last 50 years. Proceedings of Estonian Academy of Sciences: Engineering 13(3), 252-259. 2007.

[10] Hisdal, H., Holmqvist, E., Hyvärinen, V., Jónsson, P., Kuusisto, E., Larsen, S., Lindström, G., Ovesen, N. B. \& Roald, L, Long Time Series A Review of Nordic Studies. Report by the CWE Long Time Series group. Report no. 2, prepared for the CWE project, Reykjavik, Iceland, 2003.

[11] Lehner, B. \& Döll, P., Europe's droughts today and in the future. In: Lehner, B., Hendrichs, T., Döll, P. \& Alcamo, J. (eds). EuroWasser Model-based assessment of European water resources and hydrology in the face of global change. Center for Environmental Systems Research, Kassel, 2001.

[12] Järvet, A., Influence of hydrological factors and human impact on the ecological state of shallow Lake Võrtsjärv in Estonia. Dissertationes Geographicae Universitatis Tartuensis, 2007. 
[13] Gauci, V., Dise, N. \& Fowler, D., Controls on suppression of methane flux from a peat bog subjected to simulated acid rain sulfate deposition. Global Biogeochemical Cycles, 16(1), X1-X12. 2002.

[14] Gauci, V. Matthews, E., Dise, N., Walter, B., Koch, D., Granberg, G. \& Vile, M., Sulphur pollution suppression of the wetland methane source in the 20th and 21st centuries, Proceedings of the National Academy of Sciences of the USA 101, 12583-12587. 2004.

[15] Evans, C.D., Monteith, D.T. \& Cooper D.M., Long-term increases in surface water dissolved organic carbon: Observations, possible causes and environmental impacts. Environmental Pollution 137, 55-71. 2005.

[16] Findlay, S.E.G., Increased carbon transport in the Hudson River: unexpected consequence of nitrogen deposition? Frontiers in Ecology and the Environment. 3(3), 133-137. 2005.

[17] Roulet, N. \& Moore, T.R., Browning the waters - comment. Nature 444, 283-284. 2006.

[18] Treier, K., Pajuste, K. \& Frey, J., Recent trends in chemical composition of bulk precipitation at Estonian monitoring stations 1994-2001. Atmospheric Environment 38(40), 7009-7019. 2004.

[19] Xu, X.Y.\& Thomson, N.R., Estimation of the maximum consumption of permanganate by aquifer solids using a modified chemical oxygen demand test. Journal of Environmental Engineering 134, 353-361. 2008.

[20] Cirmo, C.P. \& Driscoll, C.T., The impacts of watershed $\mathrm{CaCO}_{3}$ treatment on stream and wetland biogeochemistry in the Adirondack Mountains. Biogeochemistry 32, 265-297. 1996. 